\section{Scandinavian sports medicine congress with high impact}

\author{
Karen Kotila, ${ }^{1}$ Thomas Bandholm, ${ }^{2}$ Kristian Thorborg, ${ }^{3}$ Carsten B Juhl, ${ }^{4,5}$ \\ Merete Møller, ${ }^{4}$ Heidi Klakk ${ }^{6}$
}

Welcome to this year's Danish Society of Sports Physical Therapy issue. We highlight some of the researchers whose work we had the privilege of presenting at the Scandinavian Congress of Medicine and Science in Sports in Copenhagen, February 2018. You can find, republished from the BMJ, the paper: 'Education plus exercise versus corticosteroid injection use versus a wait and see approach on global outcome and pain from gluteal tendinopathy prospective single blinded randomised clinical trial' (see page 1464). The first author is Rebecca Mellor, the senior author Sports Physiotherapy Professor Bill 'Veni, Vidi, Vici' Vicenzino. Watch a short interview with Professor Bill Vicenzino, the winner of the oral presentation competition of Scandinavian Congress of Medicine and Science in Sports (SCMSS) 2018 in Copenhagen, online (https://youtu.be/ B_ygENDeIy0).

In addition, in this issue we also dig into the topic of how to make research relevant for stakeholders and end-users such as the clinicians, coaches or athletes. As a follow-up editorial to 'Slow down to strengthen sport and exercise medicine research' (Br J Sports Med 2017;51:1453), Professor Thomas Bandholm et al (Copenhagen) give their take on how to keep research REAL with an emphasis on identifying stakeholders and end-users as well as considering their input (see page 1407). On the same topic, Dr Susan C Slade advocates for an

${ }^{1}$ Danish Society of Sports Physical Therapy, Odense, Denmark

${ }^{2}$ Clinical Research Centre, Copenhagen University Hospital, Hvidovre, Copenhagen, Denmark

${ }^{3}$ Sports Orthopaedic Research Center-Copenhagen (SORC-C), Arthroscopic Center, Department of Orthopedic Surgery, Amager-Hvidovre Hospital, Copenhagen University Hospital, Copenhagen, Denmark

${ }^{4}$ Department of Sports Science and Clinical

Biomechanics, University of Southern Denmark, Odense, Denmark

${ }^{5}$ Department of Occupational Therapy and Physiotherapy, Herlev and Gentofte Hospital, Herlev, Denmark

${ }^{6}$ Centre for Research in Childhood Health, Institute of Sports Science and Clinical Biomechanics, University of Southern Denmark, Odense, Denmark

Correspondence to Karen Kotila, Danish Society of Sports Physical Therapy, Odense 5000, Denmark; kkotila@live.dk increased use of qualitative research in sport and exercise medicine, in particular to get an understanding of stakeholders' and end-users' priorities (see page 1409). Finally, Associate Professor Carsten Juhl et al from the University of Southern Denmark presents a critical input on when it is relevant to perform a systematic review (see page 1408), based on the report from the workshop at McMaster University and Professor Gardner's article 'When and how to update systematic reviews: consensus and checklist' (BMJ 2016;354:i3507).

In February 2018, we celebrated the end of an era. The Scandinavian Foundation of Medicine and Science in Sports launched Scandinavian Congress of Medicine and Science in Sports (SCMSS) in 1992. SCMSS was held in collaboration among the Nordic countries every 2 years up until 2018 when the Foundation and SCMSS were dissolved. The decision to dissolve the Foundation and SCMSS gave rise to a proposal from Danish Association of Sports Medicine (DIMS) and Danish Society of Sports Physical Therapy (DSSF). We suggested to our Nordic sister organisations to join the scientific committee of the Danish Sports Medicine Congress (\#sportskongres), and this gives rise to a new and improved annual Scandinavian Sports Medicine Congress-in Denmark.

\section{HOW TO BUILD A SUCCESSFUL CONGRESS: KEY COMPONENTS}

Every congress has its trademark and the diversity of congresses in the world of sport and exercise and medicine makes each one an interesting encounter. We have experienced that there are key components to building a successful congress:

Continuity in the organising committee is key! It is important to stand on a solid foundation built by your predecessors and consider their advice. When people in key positions in the organisation change, it is a good idea to have the predecessor shadow the newcomer.

\section{THE END OF AN ERA: THE RISE OF A NEW COLLABORATION}

Stakeholders and end-users - ask yourself why and for whom! DIMS and DSSF have made the conscious decision that our congress is our flagship, giving sport and exercise medicine a common platform. We include four parallel tracks: sports physical therapy, sports orthopaedics, sports medicine rheumatology and workshops with clinically applied research and multidisciplinarity as common denominators.

Engagement-there are many people involved in organising a congress and these people are the best advocates of the congress. The involvement of students is key to build a bridge for the future-and let us face it: they have technical expertise and social media skills that we old-timers could never dream of! Also, bring balance to the workforce by including the new and unknown, who will engage themselves $100 \%$. Due to their busy schedule, researchers and clinicians in senior positions may not have the time to put in the hours, but they can bring in the names due to their extensive network.

Networking-a congress is the perfect place for networking. Make time and space for networking and meetings in between sessions. Our \#sportskongres app also gives people the opportunity to connect by signing up as participant.

Social gathering-there are many ways of connecting with people. Dancing is one great way of connecting people, and the floor is always packed when the band hits the first note.

Upload and share-we are aware that only a fraction of end-users find their way to our congress. Therefore, we must bring the music to them. We encourage our speakers to give us permission to upload presentations for public sharing on our YouTube channel and \#sportskongres app (https://itunes.apple.com/dk/ app/sportskongres/id1012848011? 1= $\mathrm{da} \& \mathrm{mt}=8)$, as well as giving short interviews on their area of expertise.

\section{SCANDINAVIAN SPORTS MEDICINE CONGRESS (\#SPORTSKONGRES) 2019}

We welcome you to our first Scandinavian Sports Medicine Congress in Copenhagen 31 January to 2 February 2019 (figure 1). On the topic 'Injury prevention works-how do we put it into action?', prominent speakers such as Professor Evert Verhagen and Dr Sheree Bekker are lined up. Professor Peter Magnusson, Dr Monika L Bayer and Professor Jess Snedeker will visit the topic of 'The complexity of muscle 


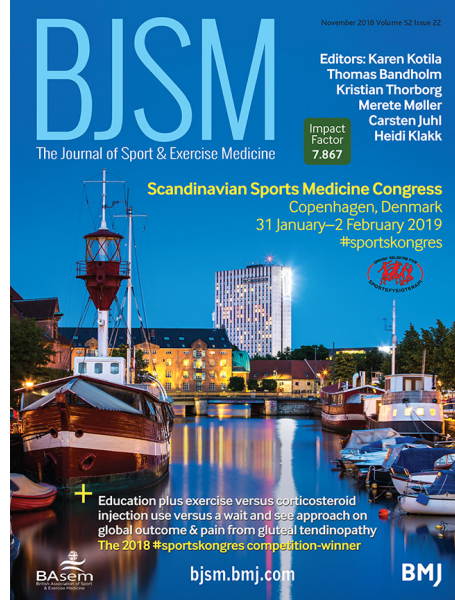

Figure 1 The Scandinavian Sports Medicine Congress will be held in Copenhagen from 31 January to 2 February 2019. strain injuries-not just an injury in the muscle'. Professor Bill Vicenzino as the keynote speaker will discuss the management of common musculoskeletal complaints: 'When to what for whom?'

We encourage you to submit an abstract for presentation-this gives you the chance to be selected for the famous oral presentation competition judged by editors from several high-ranking sport and exercise medicine journals. Finalists from the past 2 years have published their work in New England Journal of Medicine and the $B M J$, so the standard is set. The line-up is incredible, the party unforgettable and you are certain to bring home the news in clinically applied research as well as getting an expanded network. You may follow the updated programme on www.sportskongres.dk and \#sportskongres app.

Collaborators Danish Society of Sports Physical Therapy.

Contributors Cover photo: photographer Søren Dam Thomsen.

Competing interests None declared.

Patient consent Not required.

Provenance and peer review Commissioned; internally peer reviewed.

(c) Author(s) (or their employer(s)) 2018. No commercial re-use. See rights and permissions. Published by BMJ.

\section{Check for updates}

To cite Kotila K, Bandholm T, Thorborg K, et al. Br J Sports Med 2018;52:1405-1406.

Br J Sports Med 2018;52:1405-1406. doi:10.1136/bjsports-2018-099989 